\title{
Batch and continuous production of propionic acid from whey permeate by Propionibacterium acidi-propionici in a three-electrode amperometric culture system
}

\author{
Beate Schuppert, Bernhard Schink*, and Walter Trösch \\ Fraunhofer-Institut für Grenzflächen- und Bioverfahrenstechnik, W-7000 Stuttgart 80, Federal Republic of Germany
}

Received 28 January 1992/Accepted 14 April 1992

\begin{abstract}
Summary. Growth of Propionibacterium acidi-propionici was studied on lactose as substrate and in acid whey permeate in a three-electrode poised-potential system with cobalt sepulchrate as artificial electron donor. In batch culture experiments in a stirred-tank reactor the substrate was fermented completely to propionic acid up to $6.5 \mathrm{~g} \mathrm{l}^{-1}$ lactose in a supplemented whey permeate medium. No acetic acid was produced during the growth of $P$. acidi-propionici. An electron flow of $80-100 \mathrm{~mA}$ was obtained and the electron balance was $101 \%$. In continuously growing cultures with $3 \mathrm{~g} \mathrm{l}^{-1}$ of lactose as the substrate, propionate was formed as the only fermentation product up to a dilution rate (D) of $0.04 \mathrm{~h}^{-1}$. With $\mathrm{D}>0.04 \mathrm{~h}^{-1}$ the bacteria immobilized on the working electrode surface. It was examined whether an electron transfer occurred between the platinum working electrode and the immobilized cells.
\end{abstract}

\section{Introduction}

Whey and whey permeate, by-products of cheese manufacture, create a world-wide problem of waste disposal of considerable proportions. Untreated whey is used in animal feed (Skupin et al. 1977) and after a drying process whey powder is added to human food and animal feed. Whey proteins are increasingly used as protein supplements (Al-ani et al. 1972). The protein-poor ultrafiltrate of whey, the permeate, still has a high chemical oxygen demand (COD) of $50-60 \mathrm{~g} \mathrm{O}_{2} \mathrm{~kg}^{-1}$ permeate, which is mainly caused by its content of lactose and lactate. Some microorganisms can use these substrates as carbon and energy sources and produce useful fermentation products. After separating the biomass and the fermentation products, the COD of the permeate is reduced to acceptable values. Whey permeate is used as a fermentation feed stock in the manufacture of fuel alco-

* Present address: Universität Konstanz, Lehrstuhl Mikrobiologie, Universitätsstr. 10, W-7750 Konstanz, FRG

Correspondence to: $\mathrm{W}$. Trösch hol for gasohol in dairy manufacturing regions of the U.S.A. (Zall 1984), in biomass production (Zadow 1984; Vananuvat and Kinsella 1975; Marth 1970), in production of lactic acid (Mehaia and Cheryan 1987; Krischke et al. 1991), vitamin $\mathbf{B}_{12}$ (Berry and Bullerman 1966), and propionic acid (Bodie et al. 1987; Border et al. 1987; Boyaval and Corre 1987).

Biologically produced propionic acid is beneficial as a preservative agent mainly for bakery products in the food industry and for grain preservation. Other applications for propionic acid are as cellulose plastics, herbizides, plasticizers and solvents (Playne 1985). Propionic acid is hardly ever formed as the sole fermentation endproduct from sugars as fermentable substrates. The formation of propionic acid as a more reduced end-product is always accompanied by the formation of acetic acid as a more oxidized end-product. Usually the ratio from propionate to acetate is $2: 1$ and is dependent on the hydrogen and redox balance of the cellular metabolism. So far, few attempts have been made to enhance the propionic acid yield. Propionate formation increases during cultivation of the Gram-negative and hydrogenase-containing bacterium Propionispira arboris (Schink et al. 1982) under high pressures of $\mathrm{H}_{2}$ up to $16: 1$ with glucose as substrate (Thompson et al. 1984).

In an amperometric poised-potential culture system the fermentation balance of Propionibacterium freudenreichii subsp. freudenreichii is shifted towards an enhanced propionic acid formation with glucose as substrate (Emde and Schink 1990). Anthraquinone 2,6-disulphonic acid (standard redox potential $\mathrm{E}_{0}^{\prime}=-184 \mathrm{mV}$ ) and cobalt sepulchrate $\left(\mathrm{E}_{0}^{\prime}=-350 \mathrm{mV}\right)$ are used as low-potential electron carriers, which transfer electrons from a working electrode to the bacterial cells. With anthraquinone 2,6-disulphonic acid $90 \%$ and with cobalt sepulchrate as mediator $97 \%$ propionic acid are formed, but only low substrate concentrations are converted. In this paper we report the examination of enhanced propionate production during fermentation of a modified whey permeate medium by $P$. acidi-propionici. The three-electrode amperometric culture system was improved so that batch and continuously working fermen- 
tations could be carried out with higher substrate concentrations and higher working volumes.

\section{Materials and methods}

Organism, inoculum and culture media. $P$. acidi-propionici (DSM 20270) was obtained from the Deutsche Stammsammlung für Mikroorganismen (Braunschweig, FRG). Stock solutions were maintained at $-196^{\circ} \mathrm{C}$ in $\mathrm{N}_{2}$. Cultures for inoculation of the reactor were grown in a medium containing per litre: $10 \mathrm{~g}$ tryptone, $5 \mathrm{~g}$ yeast extract, $5 \mathrm{~g} \mathrm{~K}_{2} \mathrm{HPO}_{4}, 3.7 \mathrm{~g} \mathrm{KH}_{2} \mathrm{PO}_{4}, 1 \mathrm{~g} \mathrm{NaHCO}$, and $0.02 \mathrm{~g}$ each of $\mathrm{CaCl}_{2} \cdot 2 \mathrm{H}_{2} \mathrm{O}, \mathrm{MgSO}_{4} \cdot 7 \mathrm{H}_{2} \mathrm{O}$ and $\mathrm{NaCl}$ at $30^{\circ} \mathrm{C}$ under an $\mathrm{N}_{2}$ atmosphere in screw-capped bottles with lactose as substrate. Before inoculation of the reactor the growing cells were washed twice with a sterile salt solution. The ultrafiltration acid whey permeate (Nordmilch e. G., Zeven, FRG) supplemented with tryptone $\left(10 \mathrm{~g}^{-1}\right)$ and yeast extract $\left(1 \mathrm{~g} \mathrm{l}^{-1}\right)$ was autoclaved at $121^{\circ} \mathrm{C}$ for $20 \mathrm{~min}$. After autoclaving, the $\mathrm{pH}$ was poised to 6.8 with sterile $\mathrm{NaOH}(4 \mathrm{M})$ and $2 \mathrm{ml} / 1$ of a trace element solution (Widdel et al. 1983) was added. For experiments with controlled redox potential the permeate was diluted to a lactose concentration of 6-8 $\mathrm{g}^{-1}$ medium.

Culture conditions. Batch and continuous growth experiments were performed in a glass reactor with a 11 working volume under an $\mathrm{N}_{2}$ atmosphere with controlled pH 6.8 at $30^{\circ} \mathrm{C}$. In continuous cultures the medium and the redox mediator solution were pumped by a piston-diaphragm dosing pump (ProMinent Dosiertechnik, Heidelberg, FRG) and the fluid level was controlled with a peristaltic pump (Watson Marlow, Cornwall, UK). Steady-state conditions in continuous cultures were reached after 6-8 reactor volume changes. Experiments with poised redox potential were performed in an anoxic three-electrode poised-potential system (Emde et al. 1989) as described in Fig. 1. Before using the working electrode (a platinum net of $60 \mathrm{~cm}^{2}$, wire diameter $0.04 \mathrm{~mm}, 3600$ mesh per $\mathrm{cm}^{2}$, mesh diameter $0.125 \mathrm{~mm}$; Heraeus, Hanau, FRG) and the counter electrodes (a platinum wire, diameter $0.5 \mathrm{~mm}$ in the counter electrode compartment filled with $25 \mathrm{ml}$ medium), they were activated by glowing in a flame. All three electrodes (the reference electrode was a silver/silver-chloride electrode, point of reference: $+207 \mathrm{mV}$, Ingold, Mannheim, FRG) and the culture vessel with the medium were autoclaved at $121^{\circ} \mathrm{C}$ for $20 \mathrm{~min}$. After autoclaving, the electrodes were connected to a potentiostat (Type STP 84, Bank Elektronik, Göttingen, FRG) and the redox mediator (cobalt sepulchrate, $0.8 \mathrm{mM}, \mathrm{E}_{0}^{\prime}=-350 \mathrm{mV}$ ) was added. The working electrode potential was poised $120 \mathrm{mV}$ more negative than the standard redox potential of the mediator. The current between working electrode and counter electrode was recorded. After reaching the pre-set potential in the culture vessel, the substrate and the washed cell suspension were added with sterile syringes.

Analytical methods. Optical density of the culture broth was measured at $578 \mathrm{~nm}$. The ATP (free ATP and cellular ATP) was determined with an ATP analyser (Lumac Biocounter M 2500, The Netherlands) after extraction of the samples in Lumit-PM-buffer (Lumac, The Netherlands). Lactose and L- and D-lactic acid were analysed enzymatically by test kits (Boehringer, Mannheim, FRG). Propionic and acetic acid were determined as described earlier (Dehning and Schink 1989) by using a gas chromatograph 5790A (Hewlett-Packard, Böblingen, FRG) equipped with a flame ionization detector and a integrator 3390A (Hewlett-Packard). The glass column $(2 \mathrm{~m} \times 6 \mathrm{~mm})$ was packed $5 \%$ FFAP (free fatty acid phase), $0.5 \% \mathrm{H}_{3} \mathrm{PO}_{4}$, Volaspher A1, 120-140 mesh (HewlettPackard). The column temperature was $135^{\circ} \mathrm{C}$.

Growth yield determinations. Growth yields were calculated via the optical density or the ATP yield of the culture broth after calibrating the dry mass to these parameters. An optical density of

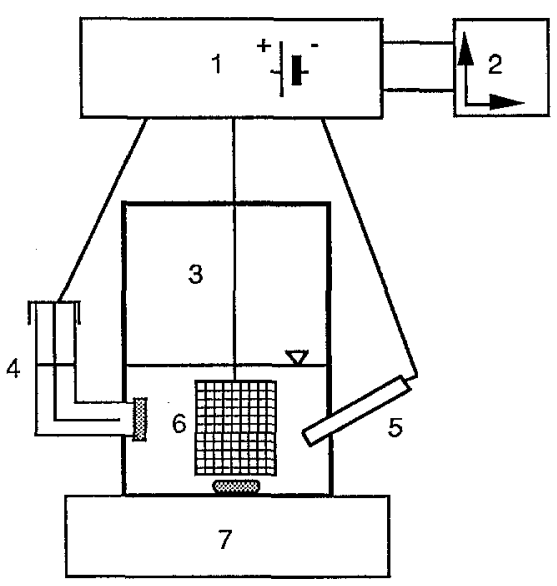

Fig. 1. Three-electrode poised-potential amperometric system: 1 , potentiostat; 2 , recorder; 3 , stirred-tank reactor; 4 , counter electrode compartment; 5 , reference electrode; 6 , working electrode; 7 , magnetic stirrer

$\Delta E_{578}=1$ corresponded to $0.64 \mathrm{~g}$ dry cell mass $1^{-1}$ and an ATP concentration equivalent of $10^{6} \mathrm{RLU}$ (relative light units) to $0.28 \mathrm{~g}$ dry cell mass $1^{-1}$.

Chemicals. All chemicals were of reagent grade quality and were obtained from Merck (Darmstadt, FRG), Fluka (Neu-Ulm, FRG), and Oxoid (London, UK). Cobalt sepulchrate was obtained from Aldrich (Steinheim, FRG).

\section{Results and discussion}

\section{Growth and product formation in acid whey permeate medium with controlled redox potential}

In a supplemented permeate medium lactose up to $40 \mathrm{~g}^{-1}$ was fermented by $P$. acidi-propionici to propionate and acetate in a ratio of $2: 1$ in $140 \mathrm{~h}$ in batch cultures without potential regulation. A propionate endconcentration of $22 \mathrm{~g} \mathrm{l}^{-1}$ and a propionate productivity of $0.15 \mathrm{~g} \mathrm{l}^{-1} \mathrm{~h}^{-1}$ was reached.

With cobalt sepulchrate as an artificial electron donor and a redox potential poised at $-470 \mathrm{mV}$ the reduction of the bacterially oxidized mediator was fast enough to keep more than $80 \%$ of the mediator in the reduced state during bacterial growth with $6.5 \mathrm{~g}^{-1}$ of lactose as substrate. Under these conditions lactose was fermented only to propionate $(100 \%$ propionate; in a control experiment without potential regulation $68 \%$ propionate was formed, Fig. 2) with a propionate productivity of $0.15 \mathrm{~g}^{-1} \mathrm{~h}^{-1}$. At higher substrate concentrations the propionate-to-acetate ratio decreased and the limiting step was the reduction of the mediator on the electrode surface (data not shown). For higher substrate concentrations and cell densities working electrodes with larger surfaces were needed. The values obtained were similar to those from $P$. freudenreichii subsp. freudenreichii and $5 \mathrm{~mm}$ glucose as substrate (about 97\% propionate) (Emde and Schink 1990) and even higher than with Propionispira arboris (about $94 \%$ propionate) cultivated under high pressures of hydrogen (Thompson et al. 1984). 

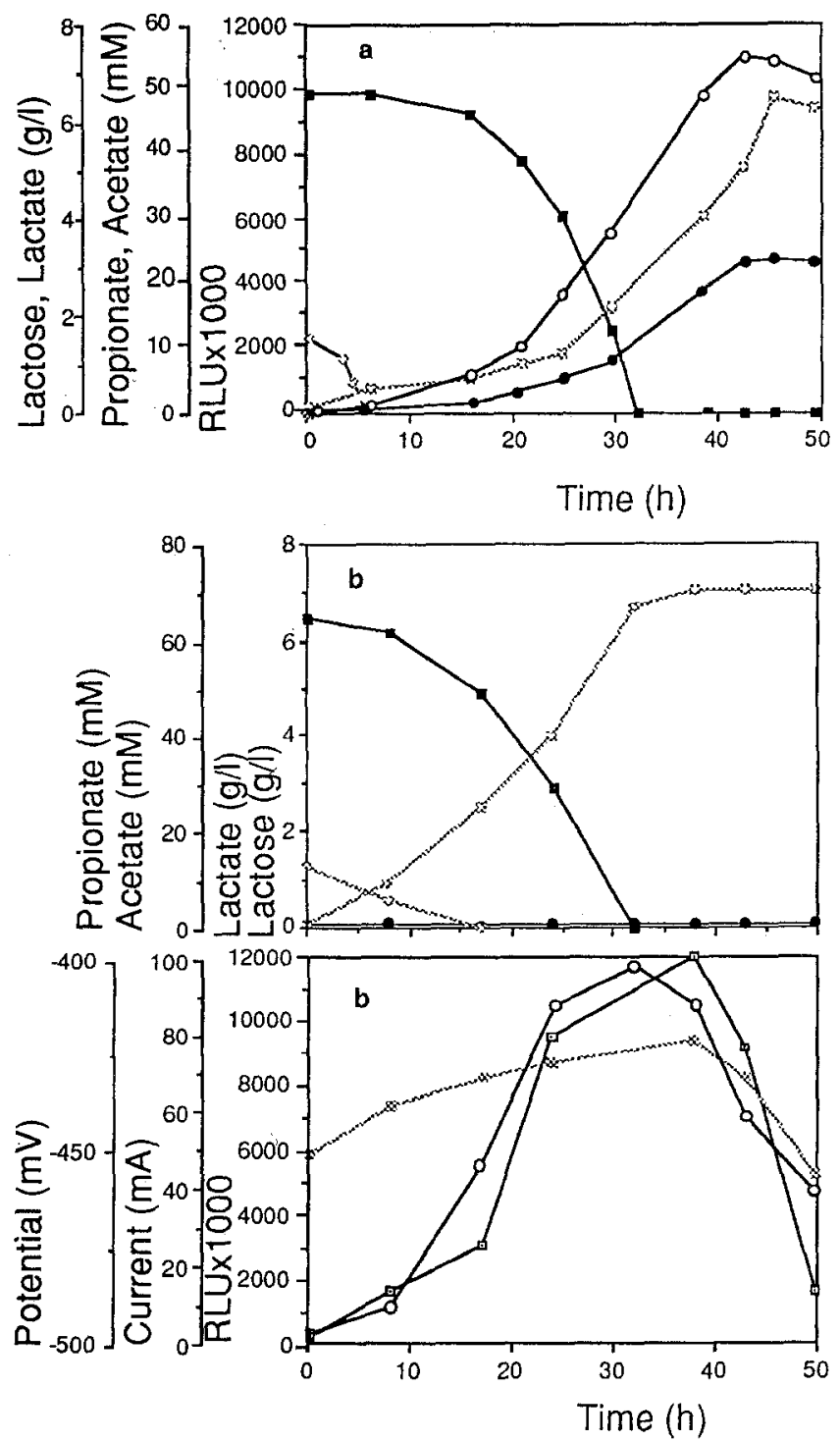

Fig. 2a, b. Biomass, substrates, products, potential, and current in Propionibacterium acidi-propionici batch cultures during growth with a permeate medium. a Control experiment without mediator and without regulated electrodes. b With cobalt sepulchrate as mediator and regulated electrodes: RLU, relative light units; $\mathbf{D}$, lactose; $\square$, current; $\diamond$, lactate; potential; $O$, acetate; $O$, RLU $\times 1000 ; \pi$, propionate
During growth a maximal current of $100 \mathrm{~mA}$ was recorded and $95.6 \mathrm{~mm}$ of electrons were transferred to the cells (carbon recovery $98.4 \%$, electron recovery $101.1 \%$, Table 1). Electron uptake, substrate consumption and propionate formation were strictly correlated (Fig. 2). The growth rate decreased to $0.08 \mathrm{~h}^{-1}$ versus $0.12 \mathrm{~h}^{-1}$ in experiments without reduced mediator. The growth yield decreased from $234 \mathrm{~g} \mathrm{~mol}^{-1}$ lactose to $188 \mathrm{~g} \mathrm{~mol}^{-1}$ lactose with controlled redox potential at $-470 \mathrm{mV}$. This corresponded to a yield loss of $20 \%$, which is higher than the expected yield loss calculated from the ATP yield changes. Similar results were reported by Emde (1990) and could be caused by inhibition of any catabolic or anabolic cellular reactions by the low redox potential of the culture broth.

\section{Growth and product formation in continuous culture}

Without regulated redox potential Propionibacterium acidi-propionici fermented lactose $\left(3 \mathrm{~g}^{-1}\right)$ to propionate and acetate in a ratio of 2 to 1 up to a dilution rate (D) of $0.13 \mathrm{~h}^{-1}$ with a maximal productivity of $0.2 \mathrm{~g} \mathrm{l}^{-1} \mathrm{~h}^{-1}$ at $\mathrm{D}=0.13 \mathrm{~h}^{-1}$. At higher $\mathrm{D}$ than $0.13 \mathrm{~h}^{-1}$ the productivity and the propionate-to-acetate ratio decreased. Data are presented in Fig. 3. The described amperometric three-electrode system was suitable to regulate the redox potential over a long time (more than $300 \mathrm{~h}$ ) and to keep the mediator in its reduced state. At $\mathrm{D}=0.04 \mathrm{~h}^{-1} P$. acidi-propionici degraded the lactose $\left(3 \mathrm{~g}^{-1}\right)$ completely to propionate as sole fermentation end-product with a productivity of $0.09 \mathrm{~g} \mathrm{l}^{-1} \mathrm{~h}^{-1}$.

At $D>0.04 \mathrm{~h}^{-1}$ the microorganisms aggregated on the surface of the working electrode and formed a biofilm. This immobilized biomass interfered with the reduction of the mediator and caused a decrease in the current from 37 to $22 \mathrm{~mA}$ (Fig. 4) at D $>0.06 \mathrm{~h}^{-1}$ and a correlated increase of the redox potential of the culture broth from $-435 \mathrm{mV}$ to $-365 \mathrm{mV}$ (data not shown).

The propionate-to-acetate ratio decreased from $100 \%$ propionate at $\mathrm{D}<0.04 \mathrm{~h}^{-1}$ to $80 \%$ propionate at a $D=0.15 \mathrm{~h}^{-1}$. Because of the immobilization of cells on the electrode surfaces the total cell number increased and lactose was completely utilized at Ds higher than

Table 1. Fermentation stoichiometry of Propionibacterium acidi-propionici after growth in the presence of cobalt sepulchrate and regulated electrodes

\begin{tabular}{|c|c|c|c|c|c|c|}
\hline $\begin{array}{l}\text { Added } \\
\text { substrate } \\
\text { (mmol) }\end{array}$ & $\begin{array}{l}\text { Acetate } \\
(\mathrm{mmol})\end{array}$ & $\begin{array}{l}\text { Propionate } \\
\text { (mmol) }\end{array}$ & $\begin{array}{l}\text { Cell material } \\
\text { formed } \\
(\mathrm{mmol})\end{array}$ & $\begin{array}{l}\text { Electrons } \\
\text { taken up } \\
(\mathrm{mmol})\end{array}$ & $\begin{array}{l}\text { Carbon } \\
\text { recovery } \\
(\%)\end{array}$ & $\begin{array}{l}\text { Electron } \\
\text { recovery } \\
(0 \%)\end{array}$ \\
\hline $\begin{array}{l}\text { 18.8 Lactose } \\
\text { 14.3 Lactate }\end{array}$ & & 70 & 13.6 & $95.6^{\mathrm{c}}$ & $98.4^{\mathrm{b}}$ & $101.1^{b}$ \\
\hline
\end{tabular}

a Control experiment without mediator

${ }^{b}$ These values include the carbon and electrons recovered as cell material (calculated as $\mathrm{C}_{4} \mathrm{H}_{7} \mathrm{O}_{3}$, Pfennig and Biebl 1976)

c Calculated from integrated current via the equation $n_{\mathrm{e}}=1 \times t \times F^{-1}$ (Emde and Schink 1990): 1, current; $t$, time; $F$, Faraday constant 


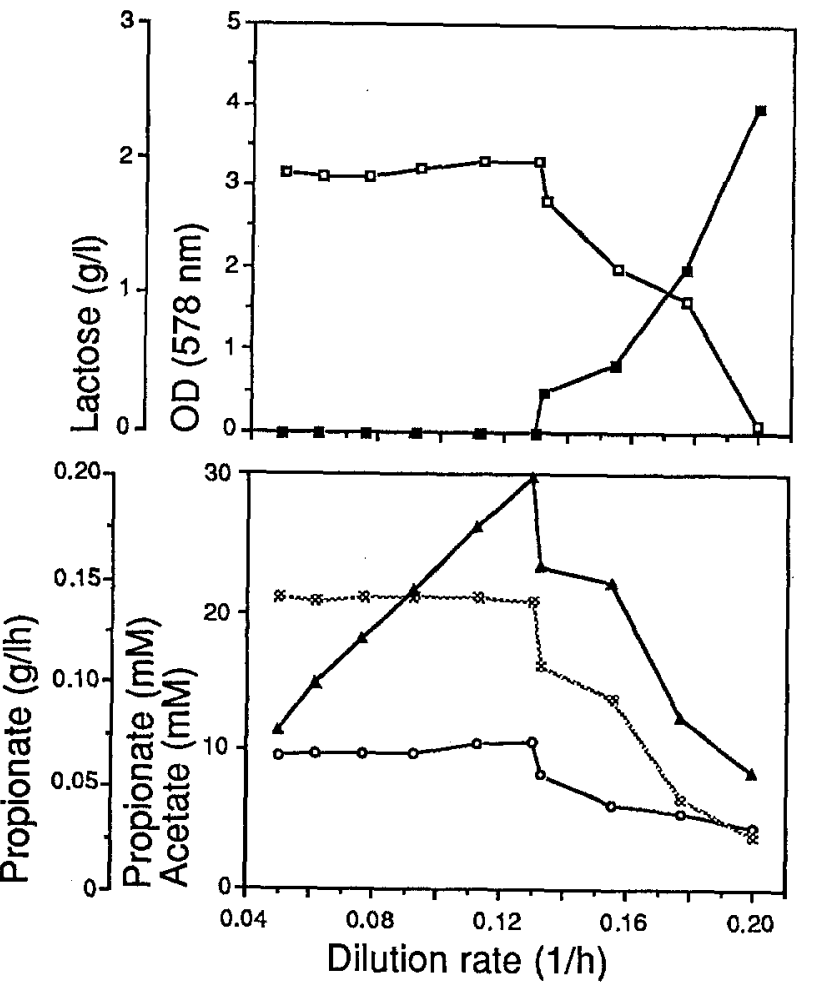

Fig. 3. Continuous culture in a stirred-tank reactor of $P$. acidipropionici at various dilution rates: $\square$, optical density at $578 \mathrm{~nm}$ [OD $(578 \mathrm{~nm})$ ]; propionate $(\mathrm{mM}) ; \boldsymbol{\square}$, lactose; $\mathrm{O}$, acetate; $\boldsymbol{\Delta}$, propionate $(\mathrm{g} / \mathrm{h})$

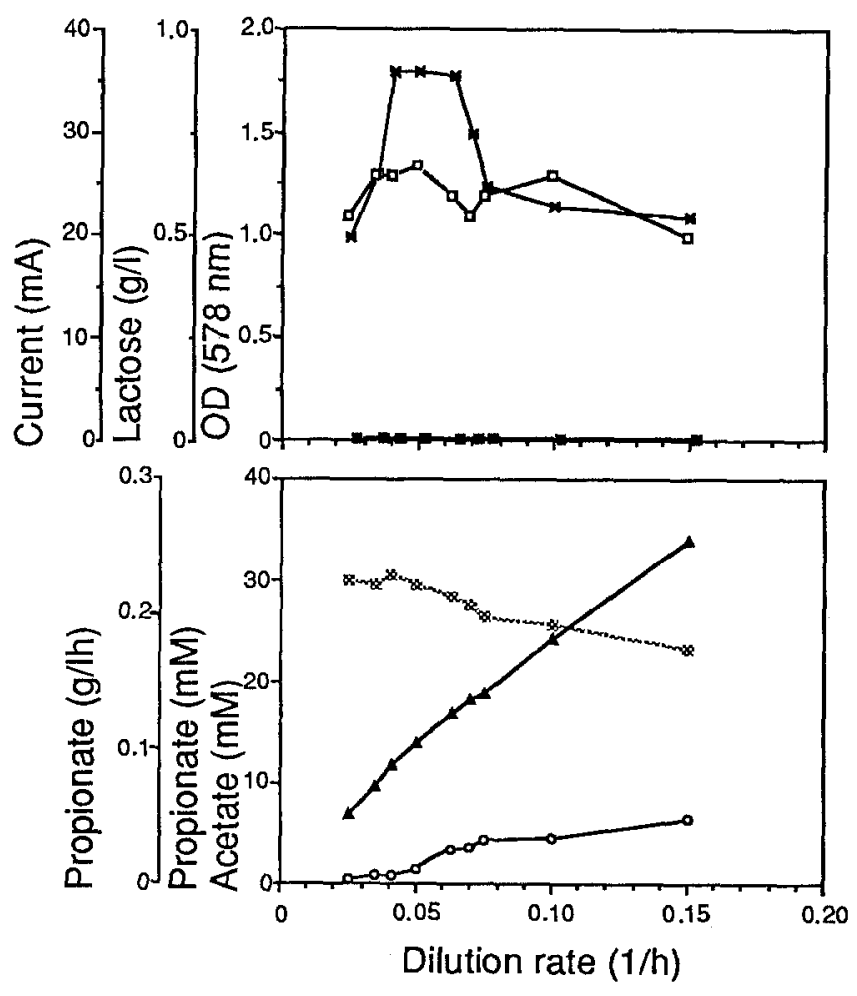

Fig. 4. Continuous culture of $P$. acidi-propionici with mediator and regulated electrodes at various dilution rates: $\square$, OD $(578 \mathrm{~nm}) ;$ propionate $(\mathrm{mM}) ; \mathbf{\square}$, lactose; $O$, acetate; $\boldsymbol{\Lambda}$, propionate $(\mathrm{g} / \mathrm{h})$
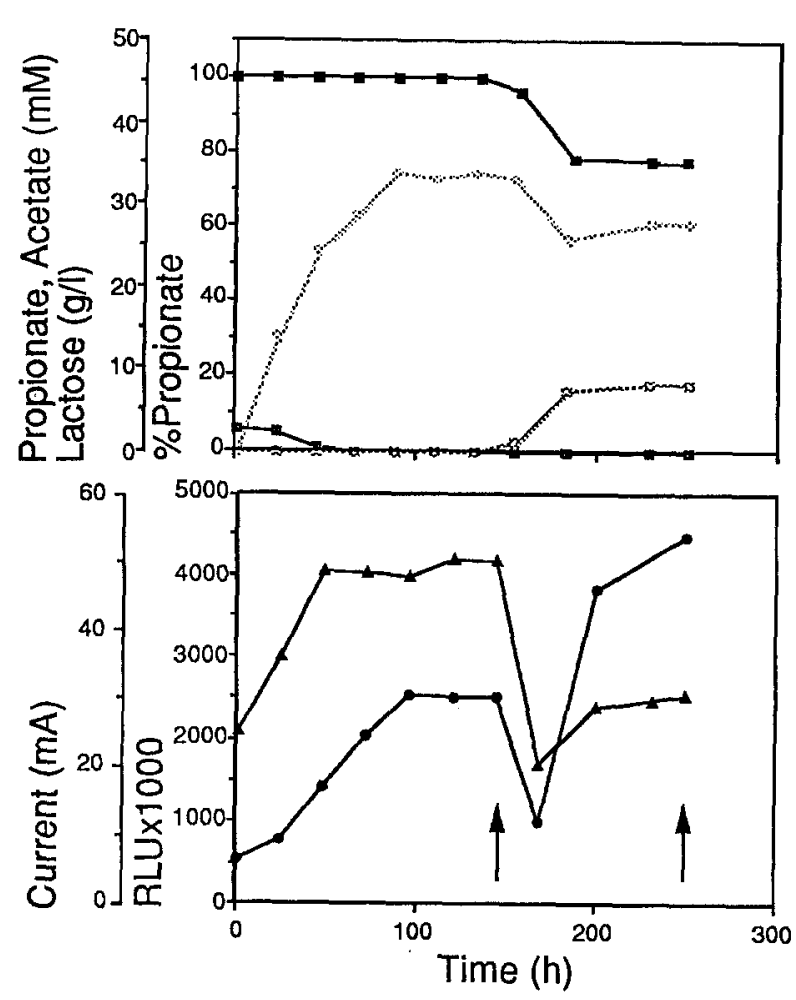

Fig. 5. Continuous culture of $P$. acidi-propionici with an exchange of the medium with mediator against medium without mediator at $t=140 \mathrm{~h}$; arrows indicate steady-state conditions: $\square$, lactose; $\boldsymbol{\Lambda}$, current; $\mathbf{a}$, acetate; $\boldsymbol{Q}, \mathrm{RLU} \times 1000$ (freely suspended cells); $;$, propionate; $\mathbf{8}, \%$ propionate

cell wash-out in the control experiment without regulated electrodes. The maximal productivity of propionate at $\mathrm{D}=0.15 \mathrm{~h}^{-1}$ was $0.26 \mathrm{~g} \mathrm{l}^{-1} \mathrm{~h}^{-1}$.

In experiments without mediator in the medium an electron transfer from the working electrode to the immobilized cells on the electrode surface occurred, which could be observed by the current between working and counter electrode. Figure 5 shows data of a continuous fermentation with constant $\mathrm{D}=0.04 \mathrm{~h}^{-1}$ with and without cobalt sepulchrate in the incoming fluid. In this experiment two forms of biomass existed: freely suspended cells in the medium and immobilized cells on the working electrode. The lactose was consumed by freely suspended cells and the immobilized biomass simultaneously. It can be supposed that after the wash-out of the mediator the suspended bacteria fermented the substrate to propionate and acetate in the usual ratio of 2 to 1 . The measured ratio of 5 to 1 could be caused by the immobilized biomass, which fermented the lactose to propionate and acetate in a higher ratio than usual. This fact should be used in a scale-up because of its two advantages. A redox mediator as artificial electron donor would be unnecessary. This will reduce the process costs and an increase in biomass concentration would improve propionate productivity.

In conclusion, the three-electrode amperometric system and cobalt sepulchrate as artificial electron donor were suitable to shift the end-product ratio of $P$. acidipropionici over a long time during continuous fermenta- 
tions. In spite of lower productivities and growth yields it was advantageous to obtain propionate as the exclusive fermentation product, because often separation of two substances is difficult.

Acknowledgements. This work was supported by the Bundesministerium für Forschung und Technologie and an industrial partner.

\section{References}

Al-ani MR, Clark HE, Howe JM (1972) Evaluation of whey as a protein supplement for wheat flour. Nutr Rep Int 5:111-118

Berry EC, Bullerman LB (1966) Use of cheese whey for vitamin $\mathrm{B}_{12}$-production. II. Cobalt, precursor, and aeration levels. Appl Microbiol 14:356-357

Bodie EA, Anderson TM, Goodman N, Schwartz RD (1987) Propionic acid fermentation of ultra-high-temperature sterilized whey using mono- and mixed cultures. Appl Microbiol Biotechnol 25:434-437

Border PM, Kierstan MPJ, Plastow GS (1987) Production of propionic acid by mixed bacterial fermentation. Biotechnol Lett $12: 843-848$

Boyaval P, Corre C (1987) Continuous fermentation of sweet whey permeate for propionic acid production in a CSTR with ultrafiltration recycle. Biotechnol Lett 11:801-806

Dehning I, Schink B (1989) Malonomonas rubra gen. nov. sp. nov., a microaerotolerant anaerobic bacterium growing by decarboxylation of malonate. Arch Microbiol 151:427-433

Emde R (1990) Beeinflussung klassischer Gärungen durch Elektroden definierter elektrischer Potentiale. Dissertation, Universität Tübingen

Emde R, Schink B (1990) Enhanced propionate formation by Propionibacterium freudenreichii in a three-electrode amperometric culture system. Appl Environ Microbiol 56:2771-2776

Emde R, Swain A, Schink B (1989) Anaerobic oxidation of glycerol by Escherichia coli in an amperometric poised-potential culture system. Appl Microbiol Biotechnol 32:170-175
Krischke W, Schröder M, Trösch W (1991) Continuous production of L-lactic acid from whey permeate by immobilized $L a c$ tobacillus casei subsp. casei. Appl Microbiol Biotechnol 34:573-578

Marth EH (1970) Fermentation products from whey. In: Byron $\mathrm{H}$, Webb PhD (eds) Byproducts from milk. AVI, Westport, Conn., pp 43-82

Mehaia AM, Cheryan M (1987) Production of lactic acid from sweet whey permeate concentrates. Process Biochem 22:185188

Pfennig N, Biebl H (1976) Rhodocyclus purpureus gen. nov. and sp. nov., a new anaerobic, sulfur-reducing, acetate-oxidizing bacterium. Arch Microbiol 110:3-12

Playne MJ (1985) Propionic and butyric acids. In: Moo-Young M (ed) Comprehensive biotechnology, vol 3. Pergamon, New York, pp 731-759

Schink B, Thompson TE, Zeikus JG (1982) Characterization of Propionispira arboris gen. nov. sp. nov., a nitrogen-fixing anaerobe common to wetwoods of living trees. J Gen Microbiol 128:2771-2779

Skupin J, Pedziwilk F, Giec A, Now Akowska K, Trojanowska K, Jaszewski B (1977) Nutritive value of propionibacteria and lactose-fermenting yeast grown in whey. J Food Process Preserv $1: 207-216$

Thompson TE, Conrad R, Zeikus JG (1984) Regulation of carbon and electron flow in Propionispira arboris: physiological function of hydrogenase and its role in homopropionate formation. FEMS Microbiol Lett $22: 265-271$

Vananuvat P, Kinsella JE (1975) Production of yeast protein from crude lactose by Saccharomyces fragilis. Batch culture studies. J Food Sci 40:336-341

Widdel F, Kohring GW, Mayer F (1983) Studies on dissimilatory sulfate-reducing bacteria that decompose fatty acids. III. Characterization of the filamentous gliding Desulfonema limicola gen. nov. sp. nov., and Desulfonema magnum sp. nov. Arch Microbiol 134:286-294

Zadow JG (1984) Lactose: properties and uses. J Dairy Sci $7: 2654-2679$

Zall RR (1984) Trends in whey fractionation and utilization, a global perspective. J Dairy Sci 67:2621-2629 